\title{
School/University Partnerships: An English Perspective
}

\section{Summary}

This paper provides an English perspective on school/university partnerships. It begins with an overview of the theoretical underpinnings of such partnerships, before examining the English school system and recent policy initiatives. It then outlines what an outstanding partnership might comprise, taken from a cut-short application made by one university to run its own University Teaching School. Finally the paper outlines some of the challenges facing extant school/university collaborations, before considering the possible futures for these partnerships.

Keywords: school/university partnerships, self-improving school system, university teaching schools, importance of Teaching White Paper

\section{Partnerschaften zwischen Schulen und Universitäten - eine englische Perspektive}

\section{Zusammenfassung}

Dieser Beitrag bietet eine englische Perspektive auf die Zusammenarbeit von Schulen und Universitäten. Er gibt zunächst einen Überblick über die theoretischen Grundlagen für solche Partnerschaften und stellt dann das englische Schulsystem und aktuelle bildungspolitische Maßnahmen vor. Anschließend führt er aus, wie eine funktionierende Partnerschaft zwischen Schule und Universität aussehen könnte; dabei bezieht er sich auf den Projektantrag einer Universität, die ihre eigene Universitätsschule einrichten wollte, die Bewerbung aber leider zurückziehen musste. Zum Abschluss geht der Beitrag auf einige Herausforderungen ein, vor denen aktuell Partnerschaften zwischen Schulen und Universitäten stehen, und erörtert die möglichen Zukunftsperspektiven solcher Partnerschaften.

Schlüsselwörter: Partnerschaften zwischen Schulen und Universitäten, Selbstoptimierung des Schulsystems, Universitätsschulen, Bedeutung der Gesetzesvorlage (White Paper) zum Unterricht 


\section{Overview}

This paper provides an English perspective on the notion of school/university partnerships. It begins by outlining the theoretical perspectives for such partnerships as well as providing a detailed overview of the state of play of the English school system. With policy initiatives now firmly supporting schools to 'self-improve' it might seem the stage is set for school/university partnerships to flourish. Yet school self-improvement has also led to the traditional domains of the university (for example in terms of initial teacher education) to be eroded. This has led to universities struggling to maintain and demonstrate relevance. It is also clear, however, that partnership working could be deeply beneficial to both schools and universities in a range of areas, from teacher education to research and development. To this end the paper then presents the possibilities of what an outstanding partnership might comprise, taken from a cut-short application made by University College London's Institute of Education to run its own University Teaching School. Finally the paper presents a brief summary of some of the challenges facing those school/university collaborations that currently do exist (or might exist in future) before considering potential future scenarios for such partnerships. It is hoped that the case study and the challenges presented in the paper provide readers with an understanding of what might contribute towards successful school/university partnerships in Germany.

\section{School/university partnerships: theory and the English context}

It is argued by Bauman (2012) that the challenges of the modern age, both in terms of their sources and their impacts, are global in nature. This means the institutions and governments of individual countries are inadequate: alone they cannot hope to make meaningful or productive inroads into the complex and often wicked problems we currently face (Rittel \& Webber, 1973). At the same time Bauman notes that the current state of 'liquid modernity' means being subject to constant change and the continuous replacement of the old with the new: "change is the only permanence, and uncertainty the only certainty" (2012, p. viii; italics in original). The aim and expectation of this change is the continual pursuit of improvement. To achieve it, structures and systems are regularly dismantled and replaced with new ways of working in order to secure better results. Particular casualties of this process in recent years, observes Bauman, have been the social institutions that have typically provided social cohesion, such as specific layers of government. In their place stand deregulation, privatisation and the onus on individual agency over collective approaches, albeit with the expectation that individuals should use their agency to learn from the best practices of others (Bauman, 2012). It is clear, however that what is and what can be learned by individuals, is enabled or constrained by the relationships within which we are immersed (Castells, 2010). Strong connections between individuals (hereafter known as 
networks) therefore lead to more potent opportunities to learn and so to improve practice.

Education has also been affected by these more general societal trends (Hargreaves \& Shirley, 2009). A network in 'education' is generally considered to represent a "group or system of interconnected people and organizations whose aims and purposes include the improvement of learning and aspects of well-being known to affect learning" (Hadfield, Jopling, Noden, O'Leary \& Stott, 2006, p. 5). The emergence of networks within education has, on one hand, been driven by the interconnected and pervasive nature of issues facing education (Díaz-Gibson, Zaragoza, Daly, Mayayo \& Romaní, 2017). Examples here include need to ensure teachers have the skills and knowledge to adapt to fast changing social and economic related educational imperatives (de Vries \& Prenger, 2018). Simultaneously, however, changes to educational structures have seen the dismantling of old ways of working and the introduction of new approaches with an individualized focus. Although this is occurring in education systems world wide (e.g. see Hargreaves \& Shirley, 2009), England, which has experienced a recent and sharp decline in the support role offered to schools from both the top and the middle tier of government (the latter known as Local Authorities), provides an exemplary case of such trends (Armstrong, 2015; Greany, 2017; Handscomb, 2018). In particular, central government policy makers in England have now devolved multiple decision-making powers and resources from Local Authorities and into schools in the belief that this will improve quality and increase innovation (Greany \& Earley, 2018).

The commitment to more 'bottom-up' school improvement was first established in the Education White Paper The Importance of Teaching. For instance a specific policy aim set out within The Importance of Teaching is that "our best schools [will] play a leadership role in driving the improvement of the whole school system, including through leading more formal federations and chains" (Department for Education, 2010, p. 60). This approach has been described elsewhere as the move towards a "selfimproving school system" (Greany, 2014, 2017); with the characteristics of 'self-improvement' including: that schools now have greater responsibility for their own improvement; that teachers and schools are expected to learn from each other so that effective practice spreads; and that schools and school leaders should be extending their reach to support other schools in improving (Greany, 2014). The focus of selfimprovement meanwhile should be on embedding a "culture of professional reflection, enquiry and learning within and across schools, [centred] on teaching and students learning" (Gilbert, 2017, p. 6).

A clear result of the push towards self-improvement is the number of schools now operating as 'Academies': either through choice or as a result of being forced to academy status as a result of poor performance (Greany, 2017). Academies are schools that operate either as companies or charities, and are outside of Local Authority funding and 
control. Although introduced by the previous New Labour government, a desire to expand the number of Academy schools was outlined in The Importance of Teaching as a means to drive educational improvement. The reason for this desired expansion relates to the freedoms Academies have to innovate. For instance Academies are not required to follow the national curriculum or employ qualified teachers (meaning they set the standards for the teachers they employ); they can also set the length of their school day as well as their own term dates (Greany, 2017). Academies can be standalone or operate as part of a Multi-Academy Trust (MAT): a formalised collaboration between a number of academies (Armstrong, 2015). As of 2017 two thirds of secondary and a fifth of primary schools in England were Academies. Of these, 50 percent of secondary schools and 60 percent of primary schools were in MATs (Greany, 2017).

To further encourage improvements in quality and innovation, policy makers have also established accountability systems that "combine quasi-market pressures (such as parental choice of school coupled with funding following the learner) with central regulation and control" (Greany \& Earley, 2018, p. 7). In particular accountability occurs via a regular school inspections process undertaken by Ofsted (England's school inspection agency). Ofsted inspections are highlighted by many school leaders as a key driver of their behaviour. As a result, it is acknowledged that England's accountability framework both focuses and places pressure on school leaders to consider only very specific forms of school improvement and so concentrate in the main on ensuring students achieve well in progress tests in key subject areas (e.g. English literacy and maths) (Greany \& Earley, 2018). At the same time, market forces can be seen influencing school choice with hierarchies of schools (in terms of parent and pupil preference) existing in local areas. Determinants of a school's position in the hierarchy include factors such as context, the composition of student intake and past reputation (Greany, 2017). While schools and school leaders work hard to reposition themselves and engineer a move up the hierarchy (often with variable results), it is also clear that low status schools do suffer from a number of challenges. These include under-subscription, student mobility and more challenging in-take, e.g. disproportionate numbers of disadvantaged, migrant and hard to place children (Greany, 2017).

As a result of both market and control-type measures, the English system can thus be regarded as one that displays both high accountability and high autonomy. The consequence of this combination of high accountability and high autonomy, along with the aforementioned focus on self-improvement, is that school leaders are now expected to be able to resolve a number of policy 'paradoxes'. In particular, Greany \& Earley (2018, p. 9) argue that school leaders are now required to:

- exercise their autonomy to provide education that meets parental needs, whilst at the same time meeting centrally prescribed targets and requirements;

- improve literacy and numeracy scores every year, whilst maintaining a broad and balanced curriculum; 
- close attainment gaps, while pushing the brightest and the best; and

- collaborate with their peers and neighbouring schools to develop skills and capacity, while competing to ensure that they move up the local hierarchy.

\section{Policy drivers for school/university partnerships}

The existence of these policy paradoxes, the liquid modern problem of self-improvement, plus the rise in "challenges for schooling that are too great for those in any one school to address alone" (Stoll, 2010, p. 4), means that one might expect a self-improving school system to provide the ideal environment for relationships between educational agents (such as schools and universities) which enable a pooling of knowledge, expertise and resource to flourish. In other words the current educational environment appears to be one in which schools would naturally seek to collaborate with universities in order to draw on resource(s) (such as knowledge and expertise) that might help them both develop effective educational practice in order to help resolve some of the paradoxes identified above. Yet the traditional domains of schools and universities have also been uprooted by the drive for school self-improvement. For instance there has been an expansion in policy initiatives such as School Direct, an approach to teacher training which provides salaried 'on the job' teacher education. Since it enables the course material to be designed by schools, Schools Direct aims to give schools a stronger role in Initial Teacher Education (ITE), thus removing this responsibility and role from universities (Greany \& Brown, 2015). Likewise networks of schools can also now be approved to run school-centred teacher education courses (these are referred to as School Centered Initial Teacher Training providers or 'SCITTs'). SCITTs provide practical, hands-on teacher training, delivered by experienced, practising teachers based in their own school or a school in their network. While SCITTS often work in close partnerships with universities, they do not have to; and where they do not, teachers completing the programme still achieve Qualified Teacher Status, they simply forego a Post Graduate Certificate in Education (the traditional teaching qualification in England that combines both educational theory and practice).

\section{School/university partnership types}

The basis for school/university partnerships in England would thus appear to be fragile. Nonetheless partnerships do, for the moment, still currently exist; and where they are active, these partnerships are typically focused on undertaking a range of innovative work in relation to: ITE, Continuous Professional Development (CPD) and Research and Development (R\&D) (Greany \& Brown, 2015). In other words, they are focused on the three main areas of overlapping interest between schools and univer- 
sity Education Departments. These areas thus represent spaces in which knowledge exchange is potentially both likely and beneficial. Of these three areas, the work on ITE is currently considered most significant, with the aim of partnership work here being to develop truly innovative learning experiences for trainee teachers (Greany

\& Brown, 2015). With regards to CPD, the role of partnerships has been to attempt to shift the focus of professional development from traditional training courses to a concept known as Joint Practice Development (JPD) (Sebba, Tregenza \& Kent, 2012). With JPD the idea is to provide time and structured approaches for teacher peer-topeer learning with explicit opportunities for teachers to learn from research (Greany \& Brown, 2015). Typically JPD is facilitated by university staff and draws on pertinent and high quality academic research. The picture on R\&D however is generally mixed: although it is valued by schools, with some innovative approaches in place such as Research Learning Communities (Brown, 2017), the lack of capacity in terms of time and funding can present genuine challenges (Greany \& Brown, 2015). Nevertheless Cain (2019) provides the following list of R\&D related activity typically associated with partnership working:

- helping schools to bid for funding for research projects;

- helping individual teachers to undertake Teacher Research Projects;

- providing research-informed CPD for teachers;

- providing and summarising research reports about topics that have been decided by the schools;

- evaluating projects which are organized and implemented by schools;

- evaluating projects which are organized by external bodies (e.g. professional artists) who are working with schools;

- planning and carrying out joint research projects, with teachers collecting data, and helping to analyse the data;

- supporting whole-school research projects which are planned by school leaders;

- recruiting schools to help with university research projects.

\section{University Training Schools}

At the same time, The Importance of Teaching did however contain within it one ray of light in relation to school/university partnerships. These were the three sentences set out within the White Paper that provided the possibility of universities to establish their own schools (referred to as University Training Schools: UTS); specifically it is stated that

"we will invite some of the best higher education providers of initial teacher training to open University Training Schools. These are used widely in Finland as a means of training teachers in practice. There are similar successful models in the US, including for example 'lab schools' in Chicago" (Department for Education, 2010, p. 23). 
One such proposal for a UTS was the Holborn and St Pancras Secondary School. Proposed both by University College London's Institute of Education (IOE) and a group of parents seeking to improve local education provision, the vision for the proposed school was very much collaborative in nature. Furthermore the notion of partnership was viewed as one that would enable the school to develop and model exemplary approaches to teacher development and learning by making a reality of the notion of research-informed teaching. In particular, one unique feature of the proposed school was that the geographical proximity between the school and the IOE was intended to enable the UTS to utilise a shared staffing model that would embed teachers within the IOE and IOE staff within the school. Ultimately, however, due to issues in securing a site near to IOE the school did not open and UCL instead sponsored an academy a few miles away (UCL Swiss Cottage School). ${ }^{1}$ Yet the proposal written in support of Holborn and St Pancras Secondary School was truly innovative and encapsulates state of the art thinking about what effective partnership working can involve. In this sense it fits squarely within Cronin's (2018) appeal to schools to "reimagine the possibilities of partnership work with universities". Correspondingly I set out below key ideas from the school proposal document as a prospective case study of school/university partnership working and to illustrate what, theoretically at least, can still be achieved. In doing so it is hoped that (as with most effective case study research) suffient detail is provided to enable readers to consider how such an approach might be applied to the German context in order to deliver desired benefits (Stenhouse, 1985).

\section{A prospective case study of school/university partnership working}

As noted above school/university partnerships in England are typically focused on ITE, teacher professional development and research and development. The aim of the Holborn and St Pancras Secondary School was no different. Specifically, a commitment to developing and retaining outstanding new entrants to teaching was intended to be at the core of the work of the UTS, while all teaching staff would play a role in training, in professional development and in research. First and foremost it was intended that each department in the school would host conventional 'teaching practice' placements, housing student teachers for at least one placement each year, usually in pairs. Close working between the school and IOE was intended to facilitate tight integration (including in philosophy, practice and norms) between the university and school-based elements of the initial teacher education offer (and indeed all other professional development programmes). The strong presence of trainees in the school was also to be harnessed to maximise school improvement through, for example, providing capacity for more in-class learning support, additional learning opportunities

1 See: http://www.uclacademy.co.uk/. 
and individual coaching for pupils. As well as the on-site training of new teachers, however, the design of the school was also intended to enable the school to offer virtual placements: here classrooms equipped with video technology would have enabled the live analysis of lessons at IOE in real time. As such these placements would have provided a means of enhancing traditional teacher education professional placements and expanding the school's capacity to provide learning and development opportunities linked directly to classroom practice. Furthermore, building on IOE's experience of piloting new approaches to ITT, the school was intended be a test-bed for new delivery models for clinically based teacher preparation.

Professional development was to occur via offering: 1) relatively conventional professional development on the school site, making use of lesson study via the school's video suite to link professional learning and development to classroom practice; 2) development work, in which staff from the school would work with staff at other schools in the area. Here the intention was that the UTS would have been innovative in drawing this development work together around a series of research and development based improvement projects, with the school coordinating work on, for example, closing attainment gaps between particular groups or developing innovative approaches to the teaching of a given subject; 3 ) developing coaching-based approaches to professional development in which staff from a number of schools work on shared projects in a school setting; 4) applying rigorous approaches to evaluating the impact of professional development on improved outcomes for students; and 5) teachers working towards a masters-level qualification to support teacher development and school improvement. It was also intended that, over time, many of these teachers would themselves become Masters degree module leaders both within and beyond the school.

A central objective of the school's UTS function was to establish a continuum of learning and development, from initial training to induction and early career development through to preparation for and support in leadership roles. The focus and driver for all development activity - for all those who work with pupils - was to ensure a positive impact on pupil learning and achievement. Here the UTS was to use baseline assessments and evidentiary evaluation to monitor the impact of teachers' learning and development on their classroom practice, the way they lead their teams and, most importantly, the impact on pupils' learning and on closing attainment gaps. In this way, the UTS was to be concerned with ensuring teachers' professional learning and was embedded as improved and sustained classroom practice, thus converting what colleagues had learnt into sustained development and improvement in practice and outcomes for pupils. Similarly there was to be a clear thread focused on improved practice and outcomes running through the school development plan, its performance management and the UTS's professional development offer, with training activity leading off from the school's and teachers' development needs. As the school grew, so would its capacity to work with neighbouring schools. 
Finally, it was intended that the UTS would enhance the interface between research and practitioners, with the UTS also itself be a site for research and development activity. In particular it was intended that the close proximity of the school to the IOE and the engagement with/of the IOE at all levels would make the school an ideal site for research into, in particular, aspects of pupil learning and progress, teaching approaches, behaviour, school management and leadership issues and issues largely specific to urban education. The governance framework and origins of the school would also provide an outstanding opportunity to link research and development into wider conceptions of community and parent engagement. More specifically it was intended that the research and development remit of the school would be developed through:

- the active engagement of the school staff in joint research projects (each staff member would, over time, have been involved in curriculum development and research);

- the school acting as a hub for research and development work across other schools: both on site, through partnership activity and through the development of the school's website as a directory of teachers' areas of expertise and a repository for related research and development projects;

- regular seminars and research projects run in partnership with the IOE;

- an annual research and development conference in the school, using the school's facilities, but run on a school closure day, for other local schools;

- opportunities for sponsored PhD studentships; and

- joint bids for external research funding.

Through the IOE's existing extensive networks with partnership schools, it was also intended that UTS teachers would be able to learn from good practice elsewhere and help the school to develop, evaluate and disseminate its own successful and innovative practice. Sabbaticals and exchange programmes involving the IOE's international partners would have also furthered opportunities open to UTS staff.

The design of the UTS also extended to the proposed architecture of the school. Here, in order to facilitate high quality learning and development from professional and virtual placements through to professional development and research engagement, the school was to benefit from being equipped with:

- digital video recording equipment in at least ten classrooms for real time observations, and mobile recording technology;

- a 'teaching lab', to allow cohorts of trainees to observe teaching in action;

- at least one large seminar room specifically for trainee teaching sessions in the UTS and CPD activities; and 
- a dedicated Teaching and Learning Development Centre: a teaching and resource base equipped with a staff development library, ICT equipment, and 'conference room' style equipment.

The school staff would also have had full access to the IOE's extensive education library. For the purposes of professional development teachers would also have had access to other facilities at the IOE, including its observation laboratory and science laboratory.

\section{Facilitating school/university partnership working}

Ultimately the UTS project described above floundered from a failure to find available and suitable space close to IOE's central London location (as noted above geographical proximity was key to the success of the approach). Whilst this was a very specific challenge facing a very specific partnership, many other challenges face current school/university collaborations, and indeed represent the extant problems associated with 'liquid modern' approaches to educational improvement. In summarizing literature relating to these challenges, Greany \& Brown (2015) suggest that key aspects to be addressed include:

- differences in language, culture and organisational priorities as well as logistical difficulties to staff physically meeting together;

- difficulties in demonstrating the impact of such partnership working and so ensuring its value is recognized;

- the need for school and university staff to have an equal voice (i.e. there should be a rejection of a hierarchical approach in which the university dominates), with practitioner priorities and knowledge explicitly valued;

- the creation of a 'third space' which is separate from the culture of either institution and allows for more creative ways of working. This cultural dialogue is powered by trust, but trust can easily be fractured if key personnel move on or priorities change.

- Partnerships and networks are not naturally self-organising. They require strategic leaders who recognise and prioritise external working of this nature as well as distributed and shared leadership across the boundaries between the partners. Opinion leaders - who may or may not be in formal roles - can also play a pivotal role in shaping and galvanising successful partnerships that overcome the cultural and practical barriers faced. Also important are the 'blended professionals' who work across institutional boundaries;

- shared aims and approaches, for example through a focus on solving locally defined problems utilising an enquiry approach; and finally: 
- Partnerships incur transaction costs - the time, energy and resources necessary to keep the partnership alive and well. Therefore funding is a crucial contributor to partnership success, but partnerships also need to develop strategies to persist in austere times.

Again these issues are derived from the English context, but it is hoped that sufficient detail is provided to enable readers to consider their applicability to the German setting. At the same time a study into school/university partnerships undertaken by Greany \& Brown (2015) highlights very specific requirements by schools from universities if partnership working is to flourish. These include: the quality and credibility of the university staff; the reputation and prestige of the university; clear indications that the university is committed to partnership working; and the ability of the university to offer expertise, wider networks as well as the role of critical friend. In particular is the need for universities to be able to demonstrate how they can align their support for ITE, CPD and R\&D, so that these different elements complement each other and meet the needs of all teaching staff over the course of their career.

\section{Moving forward}

The increased move to school self-improvement in England has left school/university partnerships in a state of flux. As a result such partnerships are both fragile and piecemeal with their characters locally determined. Since the policy drive for school self-improvement shows no signs of abating it appears clear that partnership working is likely to head in one of two ways depending on the schools and universities involved, as well as the existence of other relational factors such as historical links and personal relationships. In the first case schools may decide that partnerships with other schools are preferable to university partnerships. This is most likely to occur if working with universities is seen to offer little that a partnership of schools cannot do by itself. For example, school networks might decide to become accredited Initial Teacher Education providers (i.e. SCITTs) in their own right. Furthermore England's new Chartered College of Teaching (the professional organisation for teachers in England) ${ }^{2}$ now also seeks to provide access to high quality research articles and journals as well as support for teachers in terms of their professional development. Although this possibility is much lamented (e.g. Cronin, 2018), the danger of it occurring is very real. The second scenario is that schools instead look to form much deeper partnerships with universities. Currently only two examples of University Training Schools exist (the University of Birmingham School ${ }^{3}$ and the University of Cambridge Primary School ${ }^{4}$ ). Since these approaches to partnership are not the norm, examples of more regular and successful collaboration can be

2 See: https://chartered.college/.

3 See: https://www.birmingham.ac.uk/strategic-framework/Education/university-school.aspx.

4 See: http://universityprimaryschool.org.uk/university-training-school/. 
characterised by long-term shared working and mutual learning in order to support the career development of all staff across an alliance (Carter, 2015; Greany \& Brown, 2015). If this second scenario is to materialize however, such partnerships will need to reflect the principles of the 'third space' (described above) and the notion of 'design-led' working identified in previous research on effective school-university partnerships (Bryk, Gomez \& Grunow, 2011; Coburn, Penuel \& Geil, 2013). Likewise the potential ITE provision that could be developed through such partnerships should reflect some of the more innovative 'collaboration' models identified by Menter, Hulme, Elliot \& Lewin (2010) from international practice, for instance, the 'clinical practice' model being pioneered by the University of Melbourne. Cronin (2018) too highlights the need to show schools that it is possible to offer more 'expansive' learning experiences for beginning teachers. But what is now very apparent is that, in the extant policy environment, the onus is very much on universities to demonstrate the value of partnership working to schools if such collaborations are to form a staple feature of the English system. Only time will tell if their efforts have been sufficient.

\section{References}

Armstrong, P. (2015). Effective Partnerships and Collaboration for School Improvement: A Review of the Evidence. London: Department for Education.

Bauman, Z. (2012). Liquid Modernity. Cambridge: Polity Press.

Brown, C. (2017). Research Learning Communities: How the RLC Approach Enables Teachers to Use Research to Improve Their Practice and the Benefits for Students that Occur as a Result. Research for All, 1 (2), 387-405.

Bryk, A. B., Gomez, L. M., \& Grunow, A. (2011). Getting Ideas into Action: Building Networked Improvement Communities. Carnegie Perspectives. Accessed on 08.01.2019. Available at: http://www.carnegiefoundation.org/spotlight/webinar-bryk-gomez-build ing-networked-improvement-communities-in-education.

Cain, T. (forthcoming). Evidence-informed Practice in Schools.

Carter, A. (2015). Carter Review of Initial Teacher Training (ITT). Accessed on 04.06.2018. Available at: https://assets.publishing.service.gov.uk/government/uploads/system/up loads/attachment_data/file/399957/Carter_Review.pdf.

Castells, M. (2010). The Rise of the Network Society. Chichester: Wiley-Blackwell. doi.org/ $10.1002 / 9781444319514$

Coburn, C., Penuel, W., \& Geil, K. (2013). Research-Practice Partnerships. A Strategy for Leveraging Research for Educational Improvement in School Districts. White Paper Prepared for the William T. Grant Foundation.

Cronin, S. (2018). The Untapped Potential of University-School Partnerships. Accessed on 04.06.2018. Available at: https://www.bera.ac.uk/blog/the-untapped-potential-of-uni versity-school-partnerships.

De Vries, S., \& Prenger, R. (2018). A Lesson Study Professional Learning Network in Secondary Education. In C. Brown \& C. Poortman (Eds.), Networks for Learning: Effective Collaboration for Teacher, School and System Improvement (pp. 248-279). London: Routledge. doi.org/10.4324/9781315276649-9

Department for Education (2010). The Importance of Teaching. The Schools White Paper 2010. London: Crown Copyright. Accessed on 08.01.2019. Available at: https://www. 
gov.uk/government/publications/the-importance-of-teaching-the-schools-white-paper2010.

Díaz-Gibson, J., Zaragoza, M.C., Daly, A. J., Mayayo, M. J., \& Romaní, J. R. (2017). Networked Leadership in Educational Collaborative Networks. Educational Management Administration \& Leadership, 45 (6), 1040-1059. doi.org/10.1177/ 1741143216628532

Gilbert, C. (2017). Optimism of the Will: The Development of Local Area-based Education Partnerships. A Think Piece. London: London Centre for Leadership in Learning.

Gove, M. (2013). I refuse to Surrender to the Marxist Teachers Hell-bent on Destroying Our Schools. Accessed on 04.06.2018. Available at: http://www.dailymail.co.uk/debate/ article-2298146/I-refuse-surrender-Marxist-teachers-hell-bent-destroying-schools-Edu cation-Secretary-berates-new-enemies-promise-opposing-plans.html.

Greany, T. (2014). Are We Nearly There yet? Progress, Issues and Possible Next Steps for a SelfImproving School System. London: IOE Press.

Greany, T. (2017). Karmel Oration: Leading Schools and School Systems in Times of Change - A Paradox and a Quest. Presented at Australian Council for Educational Research (ACER) Research Conference, Melbourne, Australia, 28-29 August, 2017.

Greany, T., \& Brown, C. (2015). Partnerships between Teaching Schools and Universities: Research Report. London: UCL Institute of Education.

Greany, T., \& Earley, P. (2018). The Paradox of Policy and the Quest for Successful Leadership. Professional Development Today, 19 (3-4), 6-12.

Hadfield, M., Jopling, M., Noden, C., O'Leary, D., \& Stott, A. (2006). What Does the Existing Knowledge Base Tell Us about the Impact of Networking and Collaboration? A Review of Network-based Innovations in Education in the UK. Nottingham, UK: National College for School Leadership.

Handscomb, G. (2018). Improving the System. Professional Development Today, 19 (3-4), 4.

Hargreaves, A., \& Shirley, D. (2009). The Fourth Way: Inspiring Future for Educational Change. Thousand Oaks, CA: Corwin Press.

Menter, M., Hulme, M., Elliot, D., \& Lewin, J. (2010). Literature Review on Teacher Education in the $21^{\text {st }}$ Century. Accessed on 04.06.2018. Available at: http://www.gov. scot/Publications/2010/09/24144019/0.

Rittel, H., \& Webber, M. (1973). Dilemmas in a General Theory of Planning. Policy Sciences, 4, 155-169. doi.org/10.1007/BF01405730

Sebba, J., Tregenza, J., \& Kent, P. (2012). Powerful Professional Learning: A School Leader's Guide to Joint Practice Development. Nottingham, UK: National College for School Leadership.

Stenhouse, L. (1985). Case Study Methods. In T. Husén \& N. Postlethwaite (Eds.), The International Encyclopedia of Education (645-650). Oxford: Pergamon Press.

Stoll, L. (2010). Professional Learning Community. International Encyclopedia of Education, 151-157. doi.org/10.1016/B978-0-08-044894-7.00435-8

Chris Brown, PhD, born in 1975, Professor at the School of Education and Sociology, University of Portsmouth.

E-Mail: chris.brown@port.ac.uk

Address: University of Portsmouth, School of Education and Childhood Studies, St George's Building, 141 High Street, Old Portsmouth, PO1 2HY, U.K. 